\title{
Metabotropic Glutamate Receptor 5 Negative Allosteric Modulation Effects on Microglia Phenotype
}

by

Natasha Ari Suey Lin Curtis

A thesis submitted to the Faculty of Graduate and Postdoctoral Affairs in partial fulfilment of the requirements for the degree of

Master of Science

in

Neuroscience

Carleton University

Ottawa, Ontario

(C) 2021, Natasha Ari Suey Lin Curtis 


\section{ABSTRACT}

Microglia are the resident immunocompetent cells of the central nervous system (CNS). They are extremely plastic and critical for neurogenesis, circuit structure and function, and play a crucial role in early synapse formation. It is thought that metabotropic glutamate receptor 5 (mGluR5) plays a role in the modulation of microglial phenotype. In this thesis, we assessed the impact of the mGluR5 acting negative allosteric drug, (2-chloro-4-[2[2,5-dimethyl-1-[4-(trifluoromethoxy) phenyl] imidazol-4-yl] ethynyl] pyridine (CTEP), alone and the context of the inflammatory endotoxin, lipopolysaccharide (LPS) upon BV2 cells. This was done to assess if mGluR5 plays a role in microglia phenotype modulation. It was found that LPS has an effect on the expression of mGluR5, but otherwise did not have a significant impact upon other markers. This thesis is a starting point for future studies that seek to determine the role of mGluR5 signalling on microglial phenotype.

As a disclaimer, the principal investigator notes that this thesis is a work in progress and all data described herein, should be considered preliminary and not final. In part, the thesis was adversely impacted by infrastructure building issues at Carleton University that restricted proper access for the student. 


\section{ACKNOWLEDGEMENTS}

I would like to express my gratitude to all the members of Hayley lab. I wish to include a special thank you to Teresa Fortin whose advice and support allowed for such a prompt completion of this thesis. Also, my gratitude goes to my committee members for their valuable feedback and advice. Finally, I would like to express a special thank you to my supervisor Dr Shawn Hayley. Due to issues arising as a result of the COVID-19 pandemic and problems with access to the recently created Health Sciences Building at Carleton this has been a very valuable learning experience for me. I have learnt so much resilience and steadfastness. I would like to thank everyone who helped me stay committed to the continuing of my education through this difficult time. 


\section{TABLE OF CONTENTS}

$\begin{array}{ll}\text { ABSTRACT } & 1\end{array}$

ACKNOWLEDGEMENTS 2

TABLE OF CONTENTS

LIST OF TABLES

LIST OF ILLUSTRATIONS

LIST OF APPENDICES $\quad 5$

INTRODUCTION

BACKGROUND 6

METABOTROPIC GLUTAMATE RECEPTORS 9

G-coupled Protein Receptors $\quad 9$

Metabotropic Glutamate Receptor $5 \quad 11$

Mechanistic Target of Rapamycin $\quad 12$

HYPOTHESIS AND PROSPECTUS: A focus on mGluR5 allosteric modulation of $\begin{array}{ll}\text { microglial phenotype } & 13\end{array}$

METHODS AND MATERIALS

TISSUE CULTURE METHODS 16

CELL COUNTS 16

$\begin{array}{ll}\text { TREATMENTS } & 16\end{array}$

PROTEIN EXTRACTION

PROTEIN QUANTIFICATION

WESTERN BLOTTING 20

GEL PREPARATION $\quad 20$

FLUORESCENT IMMUNOBLOT $\quad 21$

STATISTICAL ANALYSIS $\quad 22$

RESULTS

WESTERN BLOT IMAGES 23

EFFECTS OF CTEP AND LPS ON PROTEIN EXPRESSION 25

$\begin{array}{ll}\text { DISCUSSION } & 27\end{array}$

$\begin{array}{ll}\text { Caveats and future directions } & 30\end{array}$

$\begin{array}{ll}\text { REFERENCES } & 32\end{array}$ 


\section{APPENDICES}

Appendix A

Appendix B

42

Appendix C

43

Appendix D

44

Appendix E 


\section{LIST OF TABLES}

1. Protein concentration used to create a standard curve using $0.9 \%$ sodium chloride (saline) 2,000 ug/ml Albumin Standard

\section{LIST OF ILLUSTRATIONS}

1. Figure 1. Western Blot 4E-BP1, CD11b and mGluR5 with CTEP + LPS in BV2 cells after 24 hours for each treatment...

2. Figure 2. Western blot 4E-BP1, CD11b and mGluR5 with CTEP + LPS in BV2 cells after 2 hours for each treatment...

3. Figure 3. Effect of CTEP and LPS on BV2 cells after 24 hour treatment 25

4. Figure 4. Effect of CTEP and LPS on BV2 cells after 2 hour treatment 26

\section{LIST OF APPENDICES}

A. Table 1. Abbreviation list

B. Figure 5. Western Blot 4E-BP1, CD11b and mGluR5 with CTEP + LPS in BV2 cells after 24 hours for each treatment. Biological sample 2

C. Figure 6. Western Blot 4E-BP1, CD11b and mGluR5 with CTEP + LPS in BV2 cells after 24 hours for each treatment. Biological sample 3

D. Figure 7. Western Blot 4E-BP1, CD11b and mGluR5 with CTEP + LPS in BV2 cells after 2 hours for each treatment. Biological sample 2

E. Figure 8. Western Blot 4E-BP1, CD11b and mGluR5 with CTEP + LPS in BV2 cells after 2 hours for each treatment. Biological sample 3 


\section{INTRODUCTION}

As a disclaimer, the principal investigator notes that this thesis is a work in progress and all data described herein, should be considered preliminary and not final. In part, the thesis was adversely impacted by infrastructure building issues at Carleton University that restricted proper access for the student.

\section{BACKGROUND}

Neuroinflammation is an inflammatory-like response that primarily involves the immunocompetent of the central nervous system (CNS) (Kreutzberg, 1996). Neuroinflammation is characterized by the activation of the microglia cells and the release of inflammatory cytokines and can be caused by many different events; for example, environmental stressors, trauma, microbial infections or in connection with neurodegenerative states (del Rey et al., 2013; Fleming et al., 2006; Frank et al., 2007; Streit, Mrak and Griffin, 2004). As Streit, Mrak and Griffin (2004) remark some key neurodegenerative associated pathology that can give rise to neuroinflammatory responses include, excessive tau formation, amyloid plaque formation and dystrophic neurite growth. Furthermore, neuroinflammation has been implicated in neurodegenerative diseases such as Alzheimer's disease (AD) and Parkinson's disease (PD) (Fleming et al., 2006; Frank et al., 2007; Kreutzberg, 1996; Politis, 2012).

As the first responders of the CNS, microglia orchestrate the removal and/or neutralization of potential threats to homeostasis (Gomez-Nicola and Perry, 2014; Kreutzberg, 1996). This is accomplished primarily through phagocytosis and the release of pro-inflammatory or oxidative stress factors (Tang and Le, 2015; Orihuela, McPerson, 
and Harry, 2015; Michelucci et al., 2009; Norden et al., 2016). Microglia cells are extremely plastic and are able to express an array of phenotypic states. This includes the traditionally defined $\mathrm{M} 0$ or resting/ramified microglia, $M 1$, pro-inflammatory and $M 2$, anti-inflammatory (Kettenmann, Hanisch, Noda and Verkhratsky, 2011; Orihuela, McPerson, and Harry, 2015). Although many argue that these states are not fixed and microglia can display many intermediate states (Boche, Perry and Nicoll, 2013; Kettenmann, Hanisch, Noda and Verkhratsky, 2011). Under basal conditions microglia are typically ramified in morphology and are important in the maintenance of homeostasis, CNS development and disturbances (Nayak, Roth and McGavern, 2014). Microglia typically polarize in two directions from the ramified, or $\mathrm{M} 0$, state, either classical activation of microglia, M1, is the mediator of pro-inflammatory response and alternative microglia activation or $\mathrm{M} 2$, which is typically responsible for resolution and/or repair of damage within the CNS (Franco and Fernández-Suárez, 2015; Michelucci et al., 2009; Orihuela, McPerson, and Harry, 2015; Zheng and Wong, 2019).

M1 microglial activation is defined by the presence of pro-inflammatory cytokines, such as interleukin 1 (IL-1), IL-6, and tumour necrosis factor alpha (TNF- $\alpha$ ), chemokines, cluster of differentiation 40 (CD40), CD68, and major histocompatibility complex class II (MHC-II) (Michelucci et al., 2009; Norden et al., 2016). The M2 microglial is characterized by an anti-inflammatory response, notably due to the presence of anti-inflammatory cytokines, such as IL-10, transforming growth factor beta (TGF- ), arginase-1, and Chitinase-3-like-3 (Michelucci et al., 2009; Orihuela, McPerson, and Harry, 2015). Following many insults, the M1 phenotype typically occurs first followed by the M2 phenotype (Becher, Spath and Goverman, 2016; Orihuela, McPerson, and Harry, 2015). 
In addition to being the immune cells of the brain, microglia also play a crucial role in the plasticity of individual neurons, and on a broader level microglia impact neural circuitry (Ferrini and De Koninck, 2013). Furthermore, a wide array of data has been accumulated to suggest that microglia participate in the early development of the CNS, as well as the continual modification of neural functioning and connectivity throughout adulthood (Cserép et al., 2019). Microglia participate in processes critical for synaptic plasticity, neurogenesis, circuit structure and function. They also play a crucial role in early synapse formation and elimination as well as synaptic maintenance later in life (Bar and Barak, 2019; Lorenzen et al., 2021; Nandi et al., 2012; Paolicelli et al., 2011; Paolicelli and Ferretti, 2017; Schafer et al., 2012; Wake et al., 2013). Microglia help to mediate neurogenesis, neuronal connectivity, homeostasis, synaptic plasticity and the immune response through their well-defined neuroimmune actions, such as phagocytosis or release of both pro-inflammatory and anti-inflammatory cytokines (Kreutzberg, 1996). These processes can occur in the absence of an immune stimulus or threat. Microglia also produce and respond to trophic factors, such as brain derived neurotrophic factor $(\mathrm{BDNF})$, which is an important route through which microglia can indirectly modify neuroplasticity (Coull et al., 2005; Ferrini and De Koninck, 2013; Gomes et al., 2013; Nakajima et al., 2001; Wu et al., 2020).

Following the detection of an immunogenic stimulus, such as endotoxins or infection, microglia typically undergo a series of conformational and chemical changes which result in a phenotypic change commonly referred to as the activated state (Michelucci et al., 2009; Norden et al., 2016). This is manifested in increased motility, cytokine, and the release of other soluble factors (Coull et al., 2005; Mittelbronn, Dietz, Schluesener and Meyermann, 2001; Norden et al., 2016). In some cases, this may also involve the release of neurotrophins such as BDNF, in order to provide support for 
distressed neurons (Hansen, Hanson and Sheng, 2017; Wu et al., 2020). If microglia are chronically in a pro-inflammatory state they can damage or derange otherwise healthy cells and in the worst possible scenario, this can result in massive tissue loss and degeneration of the CNS (Block et al., 2007; Lull and Block, 2010; Hansen, Hanson and Sheng, 2017).

Despite attempts to classify microglia primary phenotypes into subtypes, recent work has also highlighted a high degree of heterogeneity in these cells, particularly during early development and in injured or aged brains (Franco and Fernández-Suárez, 2015; Hammond et al., 2019). It is recognized that microglia have significantly more varied activation and resting phenotypes which express region and stimulus-specific markers (Jurga et al., 2020). This makes them interesting as these various intermediate phenotypes not only regulate normal immune sentinel patrolling, but also have important regulatory effects on neuroplasticity and neurogenesis (Mecha et al., 2015; Sackmann et al., 2017).

While much has been said about the pro-inflammatory factors and the microglial phenotype, less is known regarding the intra-cellular pathways that govern transition between activation states. It is currently unknown whether unique signalling mechanisms might dictate the various states between the M1 and M2 microglia phenotypic extremes. There are however several possible contenders, with glutamatergic pathways as a possibly important route to microglial regulation. 


\section{METABOTROPIC GLUTAMATE RECEPTORS}

\section{G-coupled Protein Receptors}

Microglial phenotype might be modulated by G-coupled protein receptors (GPCRs), which are the largest and most diverse group of eukaryotic cell surface receptors (Hilger, Masureel and Kobilka, 2018; Wu et al., 2014). GPCRs have two main signal transduction pathways: Cyclic Adenosine Monophosphate (cAMP) signal pathway and the Phosphatidylinositol signal pathway (Hilger, Masureel and Kobilka, 2018). There are six classes of GPCR, identified either by 1-6 or A-F. These classes are determined by functional similarity and homology (Basith et al., 2018; Hu, Mai and Chen, 2017). A 2008 study by Gamo et al, suggested that GPCRs are more abundant in microglia than in neurons. This is supported by more recent studies which confirm this hypothesis (Gamo et al., 2008; Haque et al., 2018; Hu et al., 2014). GPCRs are important to microglia as they play a role in the maintenance of homeostasis, phagocytosis, and trophic factor as well as inflammatory mediator release in microglia in response to stimulation in the CNS (Bhaskar et al., 2010; Hu, Mai and Chen, 2017).

Class A GPCRs are classified into rhodopsin and non-rhodopsin GPCRs, whereas class B GPCRs are secretin like receptors. The classes of GPCRs are further subdivided within the functional classifications; for example, class A GPCRs which are subdivided into aminergic-like, nucleotide-like, peptide-like, and lipid-like receptors (Basith et al., 2018). Class B GPCRs are part of the secretin family and are a key drug target for diabetes, cardiovascular disease, neurodegenerative disorders, and neuropsychiatric disorders (Bortolato et al., 2014). 
Class C GPCRs consist of metabotropic glutamate receptors (mGluR), vomeronasal type-2 receptors, gamma-amino-butyric acid (GABA) type B receptors, and extracellular calcium-sensing receptors (Wu et al., 2014). Class C GPCRs are defined as having two distinct structural features compared to other GPCR classes. Firstly, they form constitutive homodimers which have unique activation sites (Chun, Zhang and Liu, 2012; Rondard et al., 2012). Secondly, they contain a large extracellular domain that is situated away from the seven transmembrane region and contains the substrate binding sites (Chun, Zhang and Liu, 2012; Rondard et al., 2012). Furthermore, Wu et al,(2014) comment that mGluRs are comprised of a C-terminal, an N-terminal, a large hydrophilic extracellular binding region that contains conserved cysteine residues that have been implicated in disulphide bonding and a short region which contains the seven transmembrane domains.

mGluRs are a class C GPCRs which activate guanine nucleotide-binding proteins (G proteins) (Niswender and Conn, 2010; Kamato et al., 2015). G proteins are a family of proteins which are responsible for transmitting external signals into a cell in response to stimuli and act as a wide range of molecular switches (Kamato et al., 2015). There are four subcategories of $\mathrm{G}$ proteins which are defined by their a subunits (Kamato et al., 2015; Qin, Dong, Wu and Lambert, 2011). G protein alpha subunit q (Gaq) is the protein which activates the GPCR phosphatidylinositol pathway and is encoded by GNAQ (Cumbay and Watts, 2005; Qin, Dong, Wu and Lambert, 2011). The cAMP pathway is triggered by the $\mathrm{G}$ protein with a stimulatory alpha subunit (Gas), which activates adenylyl cyclase in the plasma membrane and secondary messenger cAMP activates protein kinase $A$ (PKA) (Kamato et al., 2015). 


\section{Metabotropic Glutamate Receptor 5}

mGluR5 is part of group one of known glutamate metabotropic receptors that has been shown to activate phospholipase $\mathrm{C}$, an enzyme class which is known to cleave phospholipids before the phosphate group (Doria et al., 2018). The intracellular mGluR5 pathway is thought to be responsible for, in part, the modulation of synaptic plasticity. As Jong, Kumar and O'Malley (2009) discovered, the activation of mGluR5 via glutamate results in the regulation of nuclear levels of calcium, gene expression and transcriptional activation needed for synaptic plasticity, other calcium dependent pathways, and cell survival. Other studies have found that the disruption of the mGluR5 pathway occurs in neurodegenerative disease and plays a role in behavioural and cognitive disturbances (Renner et al., 2010; Revett, Baker, Jhamandas and Kar, 2013). Some suggest that mGluR5 may be an effective target for therapeutic intervention of PD and AD (Zhang et al., 2021).

mGluR5 has at least three primary downstream pathways that might be relevant for microglial functioning: cAMP Response Element-Binding Protein (ERK-CREB), $\mathrm{Ca} 2+/$ calmodulin-dependent protein kinase II (CaMKII), and Mechanistic Target of Rapamycin Kinase (mTOR). Of these three signalling pathways, previous studies have implicated mTOR as being particularly important in inflammatory microglial responses (Keane et al., 2020; Xie et al., 2014). Moreover, it has previously been found that targeting mGluR5 with a negative allosteric drug markedly impacted mTOR signalling within the brain and promoted neural recovery in mice with a dopaminergic lesion (Farmer et al., 2020). Hence, we were particularly interested in the possibility that mGur5 mediated the mTOR pathway to influence microglial phenotype. 


\section{Mechanistic Target of Rapamycin}

mTOR is a highly conserved $289-k D a$ serine-threonine kinase with two distinct protein complexes, mTOR complex 1 (mTORC1) and mTOR complex 2 (mTORC2) (Laplante and Sabatini, 2009). The primary function of the mTOR protein complexes in the body is the regulation of cell growth and cell survival (Saxton and Sabatini, 2017). mTORC1 is known to play a primary role as a regulator of autophagy and as protein translation and cell cycle processes (Fingar and Blenis, 2004). Importantly, mTORC1 regulates Eukaryotic translation initiation factor 4E-binding protein 1 (4E-BP1) and Ribosomal protein S6 kinase beta-1 (p70S6K) activity. Which in turn, helps to control the production of trophic factors such as BDNF (Fingar and Blenis, 2004; Maiese, 2015). Within the brain, mTOR can influence neuroplastic processes through BDNF and additionally has many other effects, including glucose metabolism, mitochondrial function, autophagy, and cell growth (Perluigi, Di Domenico and Butterfield, 2015).

4E-BP1 activates eukaryotic initiation translation factor 4E (elF4E), which is a protein that plays a key role in protein synthesis by means of ribosomal recruitment and subsequent protein translation initiation (Showkat, Beigh and Andrabi, 2014; Sonenberg and Hinnebusch, 2009). As Heesom and Denton (1999) remark, the phosphorylation of 4E-BP1 by mTORC1 does not affect elF4E protein dependent translation; however, the activation of mTOR by rapamycin has been shown to dephosphorylate 4E-BP1 resulting in the loss of protein translation. This is relevant as if it is proven that 4E-BP1 is present, it can be inferred that mTORC1 is the activated mTOR protein complex as opposed to mTORC2. 


\section{HYPOTHESIS AND PROSPECTUS: A fOcus on mGluR5}

\section{negative allosteric modulation of microglial phenotype}

Modulation of GPCRs can be accomplished by targeting distinct allosteric binding sites that influence receptor conformation. Pharmacological agents that target these sites are generally classified as positive or negative allosteric modulators. Importantly, allosteric modulators do not work in traditional agonist/antagonist fashions, rather they modulate receptor sensitivity. For example, using negative allosteric modulators does not completely block receptor activity, but simply reduces overall activity.

2-chloro-4-[2-[2,5-dimethyl-1-[4-(trifluoromethoxy)phenyl]imidazol-4-yl]ethynyl]pyri dine (CTEP) is a potent negative allosteric modulator with very high selectivity for mGluR5 (Lindemann et al., 2011). While it does not directly interact with the orthostatic ligand site, CTEP has been shown to act as an inverse agonist in a non-competitive manner under basal conditions in vitro (Lindemann et al., 2011). In a study by Lindenmann et al,(2011) it was found that in an immortal cell line which were expressing human, rat, and mouse mGluR5, CTEP was able to outcompete other mGluR5 negative allosteric modulators by robustly binding to mGluR5. In the same study, it was found that when testing 103 molecular targets, including all known mGluRs, the results showed a greater than 1000-fold selectivity of CTEP for mGluR5 (Lindemann et al., 2011).

CTEP has been used as a neuroprotective treatment and has been shown to be highly orally available with half-life of 18 hours (Jaeschke et al., 2015; Lindemann et al., 2011). Lindemann et al,(2011) found that CTEP is able to cross the blood brain barrier (BBB), and is able to be safely used orally, intraperitoneally and subcutaneously in both 
adult and new-born mice. CTEP can also be safely used for injection and oral dosing in adult rats (Lindemann et al., 2011). Further studies used CTEP to successfully reduce pathology in rodents subject to a model of Fragile-X syndrome and may be useful for other neurodegenerative disorders (Jaeschke et al., 2015; Lindemann et al., 2011). Finally, in a study previously from our laboratory conducted by Farmer et al, (2020) it was discovered that CTEP promoted an increase in mTOR phosphorylation and motor behaviour recovery in 6-hydroxydopamine (6-OHDA) lesioned animals. This study concluded that CTEP, through the direct targeting and inhibition of mGluR5, helps to foster the recovery from motor deficits by promoting dopaminergic terminal sprouting in an animal model of Parkinson's disease (Farmer et al., 2020).

Although mGluR5 modulation using CTEP has yielded important neuroprotective consequences, the impact of such modulation on microglial cells is unclear. This is surprising given that microglial cells are known to express mGluR5 receptors and, like neurons, these glial cells can robustly respond to extracellular glutamate (Haas et al., 2017; Zhang et al., 2020). That said, one study did find that the alternate mGluR5 allosteric regulator, MPEP, did induce signs of basal oxidative stress in a microglial cell line (Chantong et al., 2014).

In the present thesis, we were interested in determining whether CTEP treatment would specifically influence the ability of the bacterial endotoxin, lipopolysaccharide (LPS) to provoke a typical M1 pro-inflammatory response in BV2 microglial-like cells. We hypothesized that CTEP will blunt the LPS induced morphological changes and the subsequent release of pro-inflammatory factors. We further hypothesized that these effects will be related to activation of the mTOR pathway. Whatever the case, our findings 
should be informative in the determination of how mGluR5 signalling in microglia might be important in the face of inflammatory challenges.

\section{METHODS AND MATERIALS}

As a disclaimer, the principal investigator notes that this thesis is a work in progress and all data described herein, should be considered preliminary and not final. In part, the thesis was adversely impact by infrastructure building issues at Carleton University that restricted proper access of the MSc student.

\section{TISSUE CULTURE METHODS}

BV2 cells were kindly provided by Dr David Park from the University of Ottawa. In total 24 flasks were used, four T75 flasks for each treatment group. The BV2 cells were cultured in complete media (445 mls DMEM (cat\# D6429, Sigma; Oakville, ON), $50 \mathrm{ml}$ Fetal Bovine Serum (heat treated for 30 mins) (cat\# SH30396.03, HyClone; Marlborough, MA), $5 \mathrm{ml}$ penicillin-streptomycin (cat\# P4333, Sigma). After harvesting the cells, half of the complete media $(\mathrm{CM})$ was changed every 48 hours in order to maintain the cell line.

\section{CELL COUNTS}

$30 \mu \mathrm{l}$ of the single cell suspension was added to a sterile eppendorf tube. $90 \mu \mathrm{l}$ of $\mathrm{CM}$ was added to the single cell suspension, $30 \mu \mathrm{l}$ of trypan blue (Lot \#RHBH3955, Gibco) was added to a second tube. The suspension was titrated and $30 \mu \mathrm{l}$ was added to the eppendorf tube containing trypan blue. This solution was titrated and loaded into an Incyto (Covington, GA) DHC-N01 hemocytometer, which was then placed under an Invitrogen light microscope and the cell counts were averaged. 


\section{TREATMENTS}

Treatment groups were as follows: 1 . Untreated cells, 2. CTEP treated cells(10 mM/flask, either 2 hours or 24 hours), 3. lipopolysaccharide treated cells (LPS) $(10 \mu \mathrm{g} / \mathrm{ml}$ for 2 hours and $100 \mathrm{ng} / \mathrm{ml}$ for 24 hours), or 4 . CTEP and LPS treated cells. The BV2 cells were treated with CTEP prior to LPS stimulation, and the timing of both treatments were the same across the 2 and 24 hour time points.

CTEP (Axon 1972, Axon Medchem; Groningen, The Netherlands), (10mM per flask) was added to eight T75 flasks containing $10 \mathrm{ml} \mathrm{CM}$ and BV2 cells. The flasks were returned to an incubator for two hours. The CM with CTEP (Axon 1972, Axon Medchem) was decanted and $10 \mathrm{ml}$ of fresh pre-warmed $\mathrm{CM}$ was added to each flask. A total of 10 $\mu \mathrm{g}$ in $10 \mathrm{ml}$ of LPS (Lot\# L8274, Sigma) in complete media was added to eight of the 24 flasks. The BV2 cells were incubated at $37^{\circ} \mathrm{C}$ at $5 \% \mathrm{CO}_{2}$ for 2 or 24 hours with the LPS (Lot\# L8274, Sigma).

\section{PROTEIN EXTRACTION}

After the treatment was applied and the desired time had elapsed the flasks were removed from the incubator and the conditioned media was discarded. The cells were then washed three times with ice cold Dulbeco's phosphate buffered saline (DPBS) (Lot \#RNBJ6693, Sigma). The samples were then spun at $1365 \mathrm{rpm}$ at $4^{\circ} \mathrm{C}$ for 5 minutes. The supernatant was discarded and the pellet was kept at $-80^{\circ} \mathrm{C}$.

The pellet was resuspended in $1 \mathrm{ml}$ ice cold DPBS (Lot \#RNBJ6693, Sigma) and spun at $1365 \mathrm{rpm}$ at $4^{\circ} \mathrm{C}$ for 10 minutes. The supernatant was discarded and $0.5 \mathrm{ml}$ of 
radioimmunoprecipitation assay (RIPA) like extraction buffer with Roche's complete mini EDTA-free protease inhibitor cocktail (cat \#04693159001, Roche; Basel, Switzerland) was added to each tube. The samples were sonicated repeatedly at power setting 15 for 2-3 seconds. A protein quantification was performed and the samples were loaded into a $5 X$ loading buffer at a ratio of 4:1. After the loading buffer was added the samples were heat treated at $105^{\circ} \mathrm{C}$ for 5 minutes. The samples were returned to ice for 5 minutes and stored in a $-20^{\circ} \mathrm{C}$ freezer.

\section{PROTEIN QUANTIFICATION}

The Pierce BCA protein kit (cat \#PI23225, Thermo Scientific; Ottawa, ON) was used in order to perform the following methods. To quantify the protein of the samples for western blotting analysis the previously extracted proteins were used. Reagent A (Lot \#TJ269548) and reagent B (Lot \#1859078) were used at a 50:1 ratio, with a total volume of $8.4 \mathrm{ml}$. A 96 well plate was used for quantification. The standards were made as shown in Table 1.

$25 \mu \mathrm{l}$ of each standard, S1-S9, was pipetted in duplicate. The sample protein was diluted at a ratio of $1: 30,5 \mu \mathrm{l}$ of the pure protein was added to $13 \mu \mathrm{l}$ of $0.9 \%$ sodium chloride (Hospira; Kirkland, QC). The samples were then aliquoted in triplicate into a 96 well plate. Reagents A and B were mixed and $200 \mu$ l of the mixture was pipetted into each well. The 96 well microplate was shaken at $250 \mathrm{rpm}$ for 15 seconds and incubated at $37^{\circ} \mathrm{C}$ for 30 minutes. The plate was read using a spectraMAX 190 (San Jose, CA) plate reader at $540 \mathrm{~nm}$. 
Table 1. Protein concentration used to create a standard curve using $0.9 \%$ sodium chloride (saline) 2,000 ug/ml Albumin Standard.

\begin{tabular}{|l|l|l|l|}
\hline Standard & Saline $(\mu \mathrm{l})$ & Albumin Standard $(\mu \mathrm{l})$ & Protein Concentration \\
\hline S1 & 0 & 50 & 2,000 \\
\hline S2 & 45 & 135 & 1,500 \\
\hline S3 & 110 & 110 & 1,000 \\
\hline S4 & 50 & 50 of S2 & 750 \\
\hline S5 & 110 & 110 of S3 & 500 \\
\hline S6 & 110 & 110 of S5 & 250 \\
\hline S7 & 110 & 110 of S6 & 125 \\
\hline S8 & 120 & 30 of S7 & 0 \\
\hline S9 & 50 & 0 & 25 \\
\hline
\end{tabular}




\section{WESTERN BLOTTING}

\section{GEL PREPARATION}

The $7.5 \%$ separating gel was prepared as follows for the analysis of mGluR5 using $3.75 \mathrm{ml}$ of $40 \% / 0.4 \%$ acrylamide and bis-acrylamide solution (Lot \#SLCB1332, Sigma-Aldrich; St Louis, MO), $10 \mathrm{ml} 2 \mathrm{X}$ separating buffer, $6.25 \mathrm{ml}$ distilled water $\left(\mathrm{DH}_{2} \mathrm{O}\right)$, $100 \mu \mathrm{l}$ 10\% Ammonium persulfate solution (APS) and 12.5 $\mu \mathrm{l}$ Temed (Cat \#161-0800, Biorad; Montreal, QC). The solution was mixed via gentle inversion. The separating gel was then poured into the prepared plates in the casting stands. Immediately after the gel was poured the plates were topped with 2-propanal (Lot \#SHBL2068, Sigma-Aldrich; St Louis, MA). After 45 minutes, the separating gel set and the isopropanol was discarded, the gels were then rinsed with $\mathrm{DH}_{2} \mathrm{O}$. Any excess fluid was removed using Fisherbrand (Ottawa, ON) P5 filter paper.

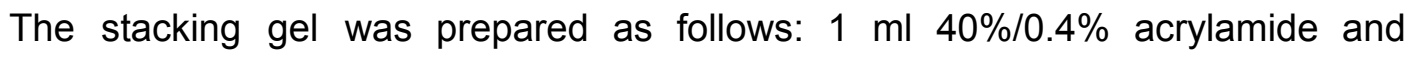
bis-acrylamide solution (Lot \#SLCB1332, Sigma-Aldrich), $5 \mathrm{ml} 2 \mathrm{X}$ stacking buffer, $4 \mathrm{ml}$ $\mathrm{DH}_{2} \mathrm{O}, 100 \mu \mathrm{l}$ 10\% APS, and $13 \mu \mathrm{l}$ Temed (Cat \#161-0800, Biorad). The stacking gel was mixed via gentle inversion, then poured onto the separating gels. The gel was allowed to polymerise for 30 minutes at room temperature.

The plates were then loaded into a BioRad (Montreal, QC) running unit and $1 \mathrm{X}$ running buffer was poured between them. The samples were then loaded into the gels 2.5 $\mu \mathrm{l}$ of Froggabio x Biohelix protein ladder (Lot \#1325244140203; Concord, ON) and $10 \mu \mathrm{l}$ of the samples in $1 \mathrm{X}$ loading buffer loaded into the lanes of the gels. Each protein 
concentration was determined experimentally. The gels were run for 60 minutes at 140 volts.

The stacking gel was removed from the separating gel and was allowed to equilibrate in $1 \mathrm{X}$ transfer buffer for 15 minutes. The Millipore Immobilon-FL PVDF fluorescent compatible membranes (Cat \#IPFL00010, Millipore-Sigma; Oakville, ON) were soaked in methanol (Lot \#SLCD2029, Sigma) for 1 minute and then transferred to $1 \mathrm{X}$ transfer buffer.

The cassettes were prepared and placed into the BioRad (Montreal, QC) transfer unit. The cassettes were prepared as follows: transfer sponge, filter paper, gel, membrane, filter paper, transfer sponge. The unit was then filled completely with pre-chilled $1 \mathrm{X}$ transfer buffer and a bio-cool unit. The transfer was run with gentle stirring, for 60 minutes at a constant voltage (100 volts). The membrane was allowed to air dry overnight in a dark place.

\section{FLUORESCENT IMMUNOBLOT}

The membranes were rehydrated in methanol for 60 seconds and then rinsed with $\mathrm{DH}_{2} \mathrm{O} .8 \mathrm{ml}$ of Fast Green stain (Cat \#F7252, Sigma) (6.7\% acetic acid, $30 \%$ methanol) $(0.0005 \%)$ was used to stain the membrane. The Fast Green (Cat \#F7252, Sigma) was allowed to incubate on the membranes for 5 minutes at room temperature on a rocker. The membranes were rinsed with a revert wash solution made of $6.7 \%$ glacial acetic acid, $30 \%$ methanol in distilled water.

The membranes were imaged on a Licor Odyssey FC system (San Jose, CA) for 2 minutes on channel 700. All the incubations and washes were done with gentle shaking in 
order to best immerse the membrane. The membrane was then blocked for 60 minutes in $10 \mathrm{ml} 0.5 \%$ fish gelatin in TBS. The blocker was decanted and $8 \mathrm{ml}$ of the primary antibodies for mTOR (GTX101557, Genetex; Irvine, CA) at 1:1000 and mGluR5 (Cell Signalling; Whitby, ON) at 1:1000, CD11-b (Lot \#GR3209213-14, Abcam) at 1:2000, CD68 (Lot \#151141B, BioRad) at 1:1000, p70S6K at 1:1000 (Lot \#9205, Cell Signalling), and 4E-BP1 at 1:1000 (Lot \#9644, Cell Signalling), $200 \mu \mathrm{l}$ of $0.2 \%$ tween and $10 \mu \mathrm{l} 0.01 \%$ SDS per $10 \mathrm{ml}$ of $0.05 \%$ fish gel in TBS-T. mGluR5, 4E-BP1, p70S6K and CD68 were incubated overnight, 18 hours, at $4^{\circ} \mathrm{C}$. The infrared conjugate, IRdye 680RD (Lot \#C81106-06, Licor; Lincoln, NE) was directed against the species of the antibodies. The membrane was then washed in Tris-buffered saline with $0.1 \%$ tween (TBS-T), then rinsed with TBS and imaged on the Licor Odyssey FC (San Jose, CA) system on channel 700.

\section{STATISTICAL ANALYSIS}

Using Jeffery's amazing statistical program (JASP) (Amsterdam, The Netherlands) one way analysis of variance (ANOVAs) were completed and all differences between treatments were subsequently analysed using Bonferroni post-hoc testing, in order to correct for sample size error $(n=3)$. All graphs were created using RStudio (Boston, MA), and all data is presented as mean \pm standard error of mean (SEM). 


\section{RESULTS}

As a disclaimer, the principal investigator notes that this thesis is a work in progress and all data described herein, should be considered preliminary and not final. In part, the thesis was adversely impacted by infrastructure building issues at Carleton University that restricted proper access of the MSc student.

In order to assess if microglial phenotype is modulated by mGluR5 expression, we used the negative allosteric modulator, CTEP, and the endotoxin, LPS, to treat BV2 microglial cells for either 2 or 24 hours. Western blotting was used to assess the protein levels in the samples. There were some visual differences seen between the western blot membranes, however after statistical analysis did not confirm these differences.

\section{WESTERN BLOT IMAGES}

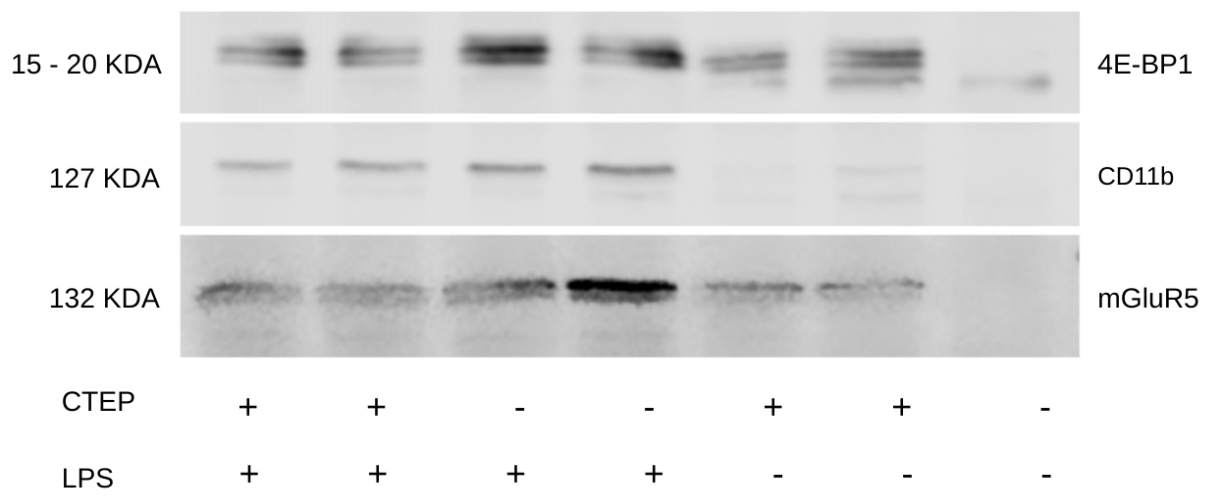

Figure 1. Western Blot 4E-BP1, CD11b and mGluR5 with CTEP + LPS in BV2 cells after 24 hours for each treatment. + indicates which treatment was applied, - indicates no treatment was applied. 4E-BP1 is known to be roughly 15-20 KDA, which is consistent with the results seen in this thesis, similarly CD11b is known to weigh $127 \mathrm{KDA}$, and mGluR5 is known to produce a $132 \mathrm{KDA}$ band when analysed in a western blot. 


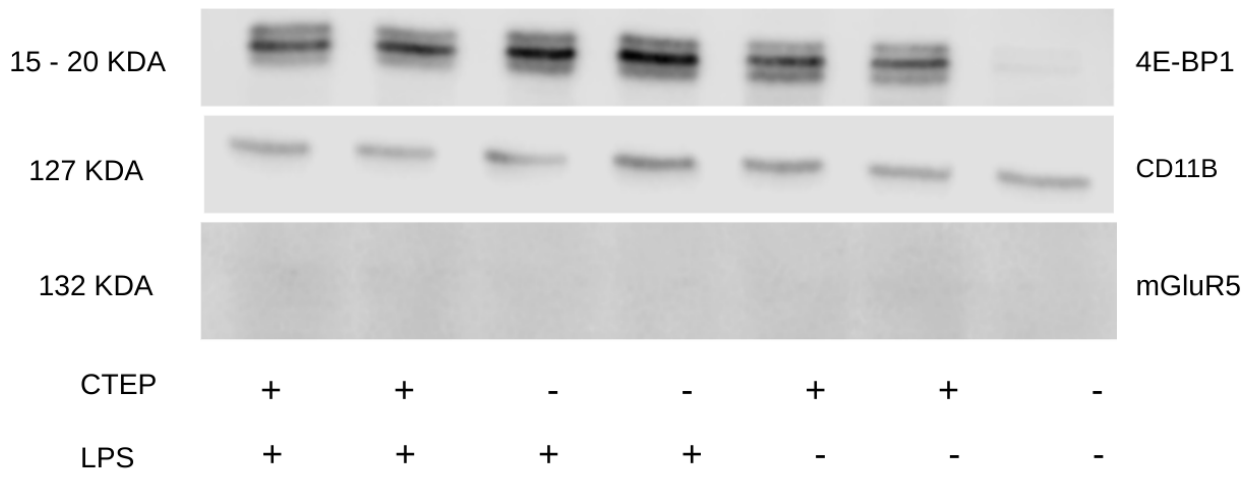

Figure 2. Western blot 4E-BP1, CD11b and mGluR5 with CTEP + LPS in BV2 cells after 2 hours for each treatment. + indicates which treatment was applied, - indicates no treatment was applied. 4E-BP1 is known to be roughly 15-20 KDA, which is consistent with the results seen in this thesis, similarly CD11b is known to weigh $127 \mathrm{KDA}$, and mGluR5 is known to produce a $132 \mathrm{KDA}$ band when analysed in a western blot. 


\section{EFFECTS OF CTEP AND LPS ON PROTEIN EXPRESSION}
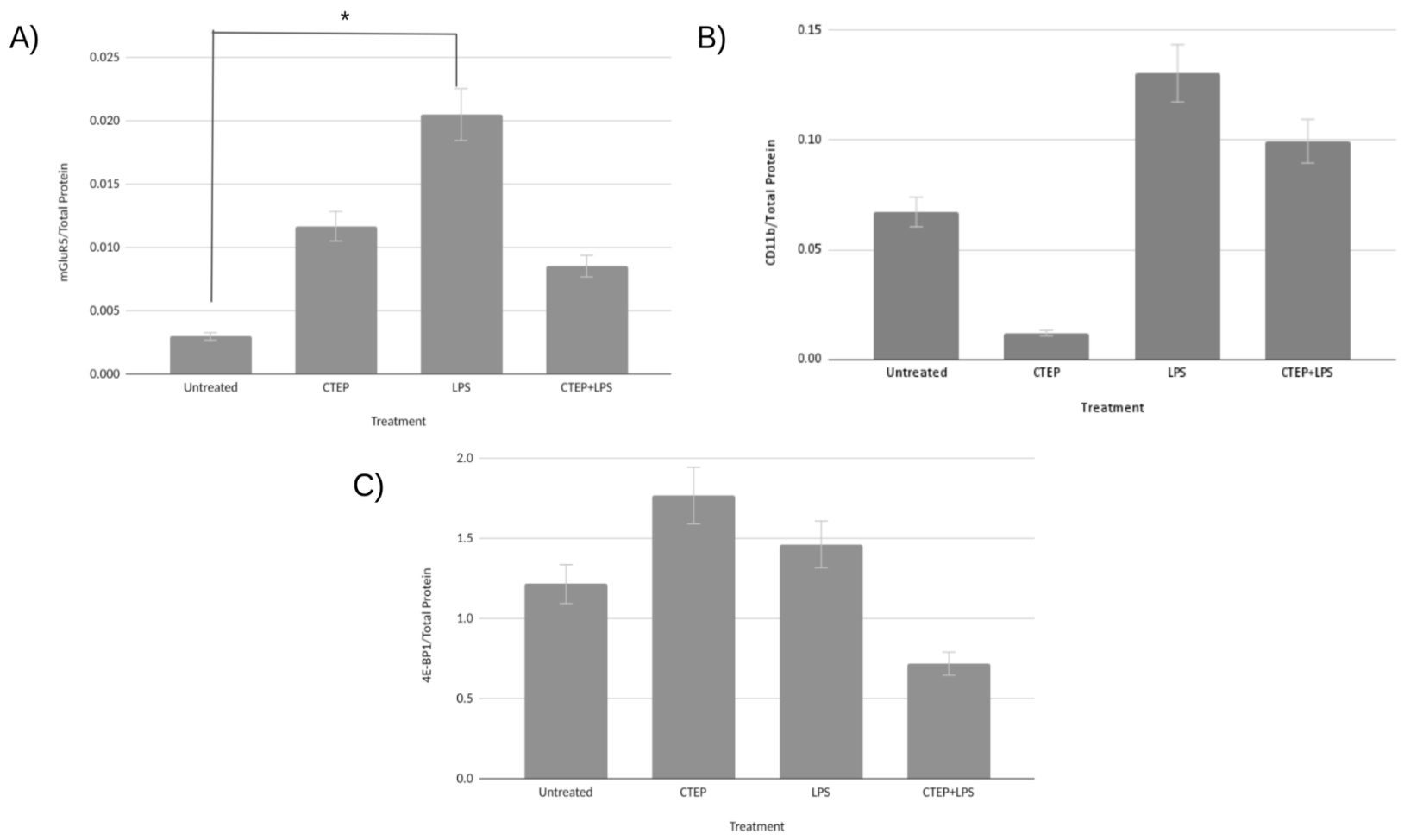

Figure 3. Effect of CTEP and lipopolysaccharide (LPS) on BV2 cells after 24 hour treatment. (A) LPS has an effect on the expression of mGluR5 after 24 hours of treatment with LPS $\left({ }^{*} p<0.05\right)$, CTEP had no effect on mGluR5 in BV2 cells when compared across the untreated group, the LPS stimulated group and the CTEP+LPS group. (B) There were no main effects observed across all treatments for CD11b expression in BV2 cells stimulated with LPS, CTEP or CTEP+LPS for 24 hours. (C) There were no main effects observed across all treatments for 4E-BP1 expression in BV2 cells stimulated with LPS, CTEP or CTEP+LPS for 24 hours. Presented data is the mean results of 3 separate experiments. All western blot signals were normalized to total protein content. Bonferroni's was used as the post hoc method.

A significant main effect was observed for BV2 mGluR5 protein levels across groups at $24 \mathrm{hrs}$ following the initial treatments (Figure $3, p=0.021$ ). The follow up comparisons indicated that LPS increased mGluR5 levels in BV2 cells, relative to unstimulated controls $(p<0.05)$. Further ANOVAs failed to reveal any other significant main effects. In particular, neither 4E-BP1 nor CD11b levels in BV2 cells varied as a function of the treatments (Figure 3). It is noteworthy to point out that CD11b appeared to be reduced by CTEP and somewhat elevated by the LPS treatment; however, these differences did not reach statistical significance. 
A)

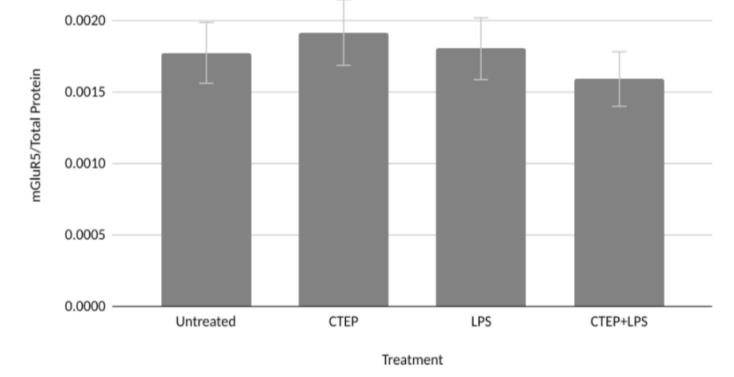

B)

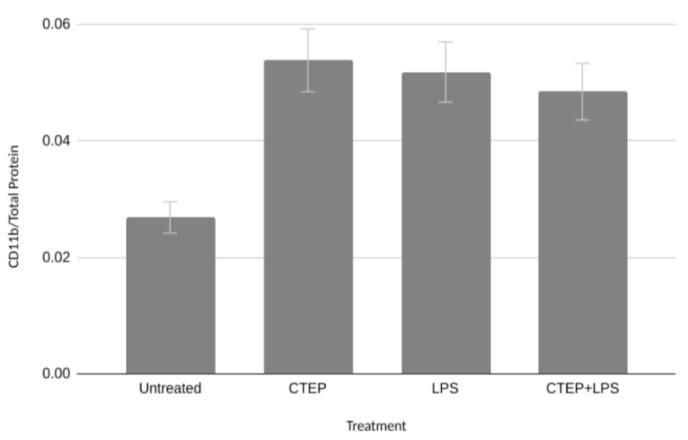

C)

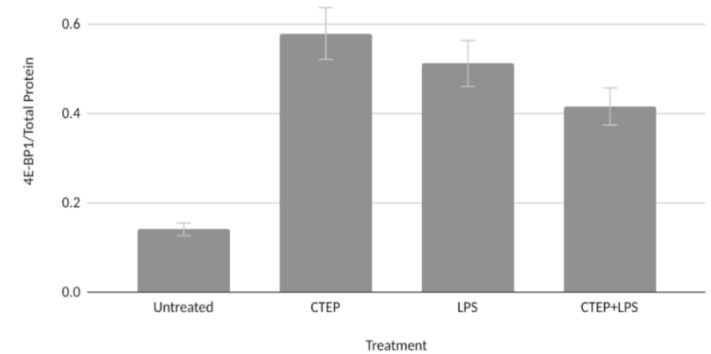

Figure 4. Effect of CTEP and LPS on BV2 cells after 2 hour treatment. (A) There were no main effects observed across all treatments for mGluR5 expression in BV2 cells stimulated with LPS, CTEP or CTEP+LPS for 2 hours. (B) There were no main effects observed across all treatments for CD11b expression in BV2 cells stimulated with LPS, CTEP or CTEP+LPS for 2 hours. (C) There were no main effects observed across all treatments for 4E-BP1 expression in BV2 cells stimulated with LPS, CTEP or CTEP+LPS for 2 hours. Presented data is the mean result of 3 separate experiments. All western blot signals were normalized to total protein content. Bonferroni's was used as the post hoc method.

No differences in either mGluR5, CD11b or 4E-BP1 were observed in the BV2 cells after 2 hours of stimulation with CTEP, LPS or CTEP+LPS (Figure 4). 


\section{DISCUSSION}

As a disclaimer, the principal investigator notes that this thesis is a work in progress and all data described herein, should be considered preliminary and not final. In part, the thesis was adversely impacted by infrastructure building issues at Carleton University that restricted proper access for the student.

Microglia are the immunocompetent cells of the CNS and play a key role in regulating neuroinflammatory responses and the maintenance of homeostasis (Bar and Barak, 2019; Ferrini and De Koninck, 2013). On top of this microglia are extremely plastic. Microglia can dynamically switch between at least three main states: resting/ramified (M0), pro-inflammatory (M1) and anti-inflammatory (M2) (Franco and Fernández-Suárez, 2015; Nayak, Roth and McGavern, 2014; Zheng and Wong, 2019). Microglia switch between the aforementioned in response to environmental challenges, such as microbial invasion, TBI, toxins and even in response to autoimmune stimuli (Bar and Barak, 2019; Lorenzen et al., 2021; Nandi et al., 2012; Paolicelli et al., 2011; Paolicelli and Ferretti, 2017). Other research shows that excessive M1 polarization of the microglia can lead to exacerbation of injury and progressive tissue destruction, otherwise known as the M1 neurotoxic phenotype which is associated with virtually all neurodegenerative diseases (Hoshi et al., 2019; Loane et al., 2014; Mass et al., 2017).

It has become clear that there are many intermediate microglial states that may influence signalling capacity (Franco and Fernández-Suárez, 2015). Among these signalling pathways, glutamatergic activity through the metabotropic glutamate receptor 5 (mGluR5) is thought to be one receptor which may be involved in microglia polarization and phenotypic modulation. To explore this, we tested the effects of the endotoxin, LPS, 
and the mGluR5 acting negative allosteric modulator, CTEP, on the BV2 microglia-like cell line. To this end, we found that mGluR5 expression was upregulated on BV2 cells when stimulated with LPS for 24 hours, suggesting a possible role for the receptor in the context of an inflammatory state. Yet, we failed to observe any significant changes in the pro-inflammatory marker, CD11b. This could be a result of technical problems since the third biological replicate (Appendix C) had values that were, in some cases, 100-fold lower than the other biological replicates which were analysed. In order to improve upon this, another biological replicate could have been made to determine if this is a trend or if this was a result of technical error. Unfortunately, the assessment of potential downstream pathways, specifically the mTORC1 downstream marker, 4E-BP1, yielded no significant changes. Hence, the findings in this thesis could serve as a starting point for future studies which would potentially further refine the understanding of the role of mGluR5 in microglial phenotype modulation and polarization.

In the absence of many experimental effects, we will revisit and further discuss mGluR5 and microglia and how emerging evidence may pave the way for potential therapeutics which target these microglial receptors. In fact, mGluR5 negative allosteric modulators have been successful in treating anxiety, depression, PD, chronic pain, addiction, and Fragile-X syndrome (Zhang et al., 2021). It should be noted that all of these CNS conditions involve a neuroinflammatory component that is characterized by excessive microglial activation (Graeber, Li and Rodriguez, 2011). CTEP itself may be especially useful since it has a highly favourable half-life of 18 hours and is highly selective for mGluR5 (Lindemann et al., 2011). CTEP has also been shown to selectively bind to mGluR5 at an affinity of 1000 times when compared to all other known metabotropic glutamate receptors (Lindemann et al., 2011). 
Previous studies have shown that mGluR5 is expressed on BV2 cells including those stimulated with LPS or negative allosteric modulators (Loane et al., 2009; Loane et al., 2014; Zhang et al., 2021). Another study by Yang et al, (2017) found that mGluR5 knockout mice showed reduced inflammatory cytokine expression, which is associated with improved brain function 24 hours following a TBI insult. Yang et al, (2017) comment that the improvements seen in the mGluR5 knockout animal model of TBI is a result of mGluR5 affecting the permeability of the blood brain barrier (BBB), specifically causing the BBB to be less permeable to neutrophils. This is relevant as it indicates that mGluR5 expression plays a key role in the regulation of the permeability of the BBB. The permeability of the BBB could be associated with the polarization of microglia and allow for new therapeutic interventions which block mGluR5 allowing for treatments to more readily cross the BBB as well as possibly aid in the modulation of microglial phenotypes.

Further research found that LPS downregulated mGluR5 expression in primary microglia and BV2 cells (Berger et al., 2012; Byrnes et al., 2009; Tilleux, Berger and Hermans, 2007). Finally, when mGluR5 was selectively activated it polarized microglia to an anti-inflammatory M2 state (Loane, et al., 2014). Loane et al, (2014) also found that treatment with LPS significantly reduced the expression of CD68 in highly activated microglia. CD68 is a very well-known inflammatory marker that implies that modulation of mGluR5 may reduce the pro-inflammatory state of microglia (Loane et al., 2014; Zotova et al., 2013). The previous study also comments on the neuroprotective effects of selective stimulation of mGluR5 following experimental TBI (Loane et al., 2014). This suggests that the neuroprotective effects may be, in part, due to the ability of mGluR5 to modulate the neurotoxic effects of post-traumatic neuroinflammation in microglia (Loane et al., 2014). Taken together with the results from the present thesis, this implicates mGluR5 in the regulation of inflammatory response in the brain and implies that it may help in the 
modulation of microglial phenotype.

A previous study conducted in our laboratory, found that CTEP improved motor deficits in an animal model of PD and that mTOR appeared to play an important role in the beneficial neurorecovery motor effects of CTEP (Farmer et al., 2020). However, this study did not assess whether the beneficial mTOR signalling was limited to neurons, or if microglial cells might also be important in recovery of motor deficits. This was one key reason for using isolated BV2 microglial cells in the present thesis. We know that based on a study by Keane et al, (2020) that the downstream factor of mTORC1, Eukaryotic translation initiation factor 4E-binding protein 1 (4E-BP1) is activated in mice after LPS stimulation and causes an increase of inflammatory cytokines. The results from the aforementioned study suggest that mTOR regulation is an interesting therapeutic target, especially to prevent neuroinflammation increases associated with aging. However, the results also illustrate the importance of understanding how mTOR regulates inflammatory processes on many levels when designing possible pharmacological interventions (Keane et al., 2020). This thesis sought to assess whether CTEP would modulate mTOR or 4E-BP1, in the hopes of developing a greater understanding of how these two factors are involved in the inflammatory response in isolated microglia. However, it was found that neither LPS nor CTEP influenced mTOR signalling factors, specifically 4E-BP1, in BV2 cells.

\section{Caveats and future directions}

Overall, the present thesis has many limitations which were exacerbated by the COVID-19 pandemic and that the Health Sciences Building at Carleton University is still not fully functional. The research facility is incomplete and animal 
services have been greatly reduced. This resulted in restricted access to the research facility for an extended period of time. In fact, several more experiments were originally planned to be completed and the original intention of the primary investigator was that the data presented would be a prelude to a much larger study, which would have included primary microglia and animal models.

One specific technical limitation of the study was that western blot analysis was solely used to quantify target proteins. It would have possibly been beneficial to utilize immunohistochemistry in order to visualize the proteins of interest, namely CD11b, CD68, and p70S6K. It would also be desirable to assess further targets that might speak to the possibility of an inflammatory reaction. This could involve soluble cytokines, which would be accessed via enzyme linked immunosorbent assay (ELISA) or potentially other proteins which are associated with an inflammatory response, for example CD68, or Allograft inflammatory factor 1 (IBA-1). Given the observed effects, more extensive dose response preliminary studies should have been conducted to determine the optimal dosing parameters for both CTEP and LPS.

In summary, this thesis is a starting point to understanding how metabotropic glutamate receptor group one plays a role in microglial polarization and phenotype modulation. To gain a more in depth understanding further analysis is required to determine how these proteins are involved in the polarization of microglial phenotypes. 


\section{REFERENCES}

Abd-Elrahman, K., Hamilton, A., Hutchinson, S., Liu, F., Russell, R. and Ferguson, S., 2017. mGluR5 antagonism increases autophagy and prevents disease progression in the zQ175 mouse model of Huntington's disease. Science Signaling, 10(510), p.eaan6387.

Basith, S., Cui, M., Macalino, S., Park, J., Clavio, N., Kang, S. and Choi, S., 2018. Exploring G Protein-Coupled Receptors (GPCRs) Ligand Space via Cheminformatics Approaches: Impact on Rational Drug Design. Frontiers in Pharmacology, 9.

Bao, Y., Qin, L., Kim, E., Bhosle, S., Guo, H., Febbraio, M., Haskew-Layton, R., Ratan, R. and Cho, S., 2012. CD36 is Involved in Astrocyte Activation and Astroglial Scar Formation. Journal of Cerebral Blood Flow \& Metabolism, 32(8), pp.1567-1577.

Becher, B., Spath, S. and Goverman, J. (2016). Cytokine networks in neuroinflammation. Nature Reviews Immunology, 17(1), pp.49-59.

Berger, J., Dumont, A., Focant, M., Vergouts, M., Sternotte, A., Calas, A., Goursaud, S. and Hermans, E., 2012. Opposite regulation of metabotropic glutamate receptor 3 and metabotropic glutamate receptor 5 by inflammatory stimuli in cultured microglia and astrocytes. Neuroscience, 205, pp.29-38.

Bhaskar, K., Konerth, M., Kokiko-Cochran, O., Cardona, A., Ransohoff, R. and Lamb, B., 2010. Regulation of Tau Pathology by the Microglial Fractalkine Receptor. Neuron, 68(1), pp.19-31.

Boche, D., Perry, V. and Nicoll, J., 2013. Review: Activation patterns of microglia and their identification in the human brain. Neuropathology and Applied Neurobiology, 39(1), pp.3-18.

Bortolato, A., Doré, A., Hollenstein, K., Tehan, B., Mason, J. and Marshall, F., 2014. Structure of Class B GPCRs: new horizons for drug discovery. British Journal of Pharmacology, 171(13), pp.3132-3145.

Burnett, P., Barrow, R., Cohen, N., Snyder, S. and Sabatini, D., 1998. RAFT1 phosphorylation of the translational regulators p70 S6 kinase and 4E-BP1. Proceedings of the National Academy of Sciences, 95(4), pp.1432-1437. 
Chantong, B., Kratschmar, D., Lister, A. and Odermatt, A., 2014. Inhibition of metabotropic glutamate receptor 5 induces cellular stress through pertussis toxin-sensitive Gi-proteins in murine BV-2 microglia cells. Journal of Neuroinflammation, 11(1).

Chun, L., Zhang, W. and Liu, J., 2012. Structure and ligand recognition of class C GPCRs. Acta Pharmacologica Sinica, 33(3), pp.312-323.

Cserép, C., Pósfai, B., Lénárt, N., Fekete, R., László, Z., Lele, Z., Orsolits, B., Molnár, G., Heindl, S., Schwarcz, A., Ujvári, K., Környei, Z., Tóth, K., Szabadits, E., Sperlágh, B., Baranyi, M., Csiba, L., Hortobágyi, T., Maglóczky, Z., Martinecz, B., Szabó, G., Erdélyi, F., Szipőcs, R., Tamkun, M., Gesierich, B., Duering, M., Katona, I., Liesz, A., Tamás, G. and Dénes, Á., 2019. Microglia monitor and protect neuronal function through specialized somatic purinergic junctions. Science, 367(6477), pp.528-537.

Cumbay, M. and Watts, V., 2005. Gaq potentiation of adenylate cyclase type 9 activity through a Ca2+/calmodulin-dependent pathway. Biochemical Pharmacology, 69(8), pp.1247-1256.

del Rey, A., Balschun, D., Wetzel, W., Randolf, A. and Besedovsky, H., 2013. A cytokine network involving brain-borne IL-1 $\beta$, IL-1ra, IL-18, IL-6, and TNFa operates during long-term potentiation and learning. Brain, Behavior, and Immunity, 33, pp.15-23.

Dibble, C., Asara, J. and Manning, B., 2009. Characterization of Rictor Phosphorylation Sites Reveals Direct Regulation of mTOR Complex 2 by S6K1. Molecular and Cellular Biology, 29(21), pp.5657-5670.

DiSabato, D., Quan, N. and Godbout, J. (2017). Neuroinflammation: the devil is in the details. Journal of Neurochemistry, 139, pp.136-153.

Doria, J., de Souza, J., Silva, F., Olmo, I., Carvalho, T., Alves-Silva, J., Ferreira-Vieira, T., Santos, J., Xavier, C., Silva, N., Maciel, E., Conn, P. and Ribeiro, F. (2018). The mGluR5 positive allosteric modulator VU0409551 improves synaptic plasticity and memory of a mouse model of Huntington's disease. Journal of Neurochemistry, 147(2), pp.222-239.

Farmer, K., Abd-Elrahman, K., Derksen, A., Rowe, E., Thompson, A., Rudyk, C., Prowse, N., Dwyer, Z., Bureau, S., Fortin, T., Ferguson, S. and Hayley, S., 2020. mGluR5 Allosteric Modulation Promotes Neurorecovery in a 6-OHDA-Toxicant Model of Parkinson's Disease. Molecular Neurobiology, 57(3), pp.1418-1431.

Fenton, T. and Gout, I., 2011. Functions and regulation of the $70 \mathrm{kDa}$ ribosomal S6 kinases. The International Journal of Biochemistry \& Cell Biology, 43(1), pp.47-59.

Ferrini, F. and De Koninck, Y., 2013. Microglia Control Neuronal Network Excitability via BDNF Signalling. Neural Plasticity, 2013, pp.1-11. 
Fingar, D. and Blenis, J., 2004. Target of rapamycin (TOR): an integrator of nutrient and growth factor signals and coordinator of cell growth and cell cycle progression. Oncogene, 23(18), pp.3151-3171.

Fleming, J., Norenberg, M., Ramsay, D., Dekaban, G., Marcillo, A., Saenz, A., Pasquale-Styles, M., Dietrich, W. and Weaver, L., 2006. The cellular inflammatory response in human spinal cords after injury. Brain, 129(12), pp.3249-3269.

Franco, R. and Fernández-Suárez, D., 2015. Alternatively activated microglia and macrophages in the central nervous system. Progress in Neurobiology, 131, pp.65-86.

Frank, M., Baratta, M., Sprunger, D., Watkins, L. and Maier, S., 2007. Microglia serve as a neuroimmune substrate for stress-induced potentiation of CNS pro-inflammatory cytokine responses. Brain, Behavior, and Immunity, 21(1), pp.47-59.

Gainetdinov, R., Premont, R., Bohn, L., Lefkowitz, R. and Caron, M., 2004. Desensitization of $\mathrm{G}$ protein-Coupled Receptors and Neuronal Functions. Annual Review of Neuroscience, 27(1), pp.107-144.

Gamo, K., Kiryu-Seo, S., Konishi, H., Aoki, S., Matsushima, K., Wada, K. and Kiyama, H., 2008. G-Protein-Coupled Receptor Screen Reveals a Role for Chemokine Receptor CCR5 in Suppressing Microglial Neurotoxicity. Journal of Neuroscience, 28(46), pp.11980-11988.

Gebicke-Haeter, P., Spleiss, O., Ren, L., Li, H., Dichmann, S., Norgauger, J. and Boddeke, H. (2004). Microglial chemokines and chemokine receptors. Progress in Brain Research, 132(2001), pp.525-532.

Gomez-Nicola, D. and Perry, V., 2014. Microglial Dynamics and Role in the Healthy and Diseased Brain. The Neuroscientist, 21(2), pp.169-184.

Graeber, M., Li, W. and Rodriguez, M., 2011. Role of microglia in CNS inflammation. FEBS Letters, 585(23), pp.3798-3805.

Haas, L., Salazar, S., Smith, L., Zhao, H., Cox, T., Herber, C., Degnan, A., Balakrishnan, A., Macor, J., Albright, C. and Strittmatter, S. (2017). Silent Allosteric Modulation of mGluR5 Maintains Glutamate Signaling while Rescuing Alzheimer's Mouse Phenotypes. Cell Reports, 20(1), pp.76-88.

Haque, M., Kim, I., Jakaria, M., Akther, M. and Choi, D., 2018. Importance of GPCR-Mediated Microglial Activation in Alzheimer's Disease. Frontiers in Cellular Neuroscience, 12. 
Hansen, D., Hanson, J. and Sheng, M., 2017. Microglia in Alzheimer's disease. Journal of Cell Biology, 217(2), pp.459-472.

Heesom, K. and Denton, R., 1999. Dissociation of the eukaryotic initiation factor-4E/4E-BP1 complex involves phosphorylation of 4E-BP1 by an mTOR-associated kinase. FEBS Letters, 457(3), pp.489-493.

Hilger, D., Masureel, M. and Kobilka, B., 2018. Structure and dynamics of GPCR signaling complexes. Nature Structural \& Molecular Biology, 25(1), pp.4-12.

Hoshi, T., Toyama, T., Shinozaki, Y., Koizumi, S., Lee, J., Naganuma, A. and Hwang, G., 2019. Evaluation of M1-microglial activation by neurotoxic metals using optimized organotypic cerebral slice cultures. The Journal of Toxicological Sciences, 44(7), pp.471-479.

Hu, G., Mai, T. and Chen, C., 2017. Visualizing the GPCR Network: Classification and Evolution. Scientific Reports, 7(1).

Hu, X., Liou, A., Leak, R., Xu, M., An, C., Suenaga, J., Shi, Y., Gao, Y., Zheng, P. and Chen, J., 2014. Neurobiology of microglial action in CNS injuries: Receptor-mediated signaling mechanisms and functional roles. Progress in Neurobiology, 119-120, pp.60-84.

Issazadeh, S., Mustafa, M., Ljungdahl, Å., Höjeberg, B., Dagerlind, Å., Elde, R. and Olsson, T., 1995. Interferon $\gamma$, interleukin 4 and transforming growth factor $\beta$ in experimental autoimmune encephalomyelitis in lewis rats: Dynamics of cellular mrna expression in the central nervous system and lymphoid cells. Journal of Neuroscience Research, 40(5), pp.579-590.

Jaeschke, G., Kolczewski, S., Spooren, W., Vieira, E., Bitter-Stoll, N., Boissin, P., Borroni, E., Büttelmann, B., Ceccarelli, S., Clemann, N., David, B., Funk, C., Guba, W., Harrison, A., Hartung, T., Honer, M., Huwyler, J., Kuratli, M., Niederhauser, U., Pähler, A., Peters, J., Petersen, A., Prinssen, E., Ricci, A., Rueher, D., Rueher, M., Schneider, M., Spurr, P., Stoll, T., Tännler, D., Wichmann, J., Porter, R., Wettstein, J. and Lindemann, L., 2015. Metabotropic Glutamate Receptor 5 Negative Allosteric Modulators: Discovery of 2-Chloro-4-[1-(4-fluorophenyl)-2,5-dimethyl-1H-imidazol-4-ylethynyl]pyridine (Basimglurant, RO4917523), a Promising Novel Medicine for Psychiatric Diseases. Journal of Medicinal Chemistry, 58(3), pp.1358-1371.

Kamato, D., Thach, L., Bernard, R., Chan, V., Zheng, W., Kaur, H., Brimble, M., Osman, N. and Little, P., 2015. Structure, Function, Pharmacology, and Therapeutic Potential of the G Protein, GÎ $\pm / q, 11$. Frontiers in Cardiovascular Medicine, 2.

Keane, L., Antignano, I., Riechers, S., Zollinger, R., Dumas, A., Offermann, N., Bernis, M., Russ, J., Graelmann, F., McCormick, P., Esser, J., Tejera, D., Nagano, A., Wang, 
J., Chelala, C., Biederbick, Y., Halle, A., Salomoni, P., Heneka, M. and Capasso, M., 2021. mTOR-dependent translation amplifies microglia priming in aging mice. Journal of Clinical Investigation, 131(1).

Kempuraj, D., Thangavel, R., Natteru, P., Saeed, D., Zahoor, H., Zaheer, S., lyer, S. and Zaheer, A. (2017). Neuroinflammation Induces Neurodegeneration. J Neurol Neurosurg Spine, 1(1), p.1003.

Kettenmann, H., Hanisch, U., Noda, M. and Verkhratsky, A., 2011. Physiology of Microglia. Physiological Reviews, 91(2), pp.461-553.

Kim, Y., Wang, W., Comte, I., Pastrana, E., Tran, P., Brown, J., Miller, R., Doetsch, F., Molnár, Z. and Szele, F., 2010. Dopamine stimulation of postnatal murine subventricular zone neurogenesis via the D3 receptor. Journal of Neurochemistry, 114(3), pp.750-760.

Kreutzberg, G., 1996. Microglia: a sensor for pathological events in the CNS. Trends in Neurosciences, 19(8), pp.312-318.

Laplante, M. and Sabatini, D., 2009. mTOR signaling at a glance. Journal of Cell Science, 122(20), pp.3589-3594.

Lian, H., Roy, E. and Zheng, H. (2016). Protocol for Primary Microglial Culture Preparation. BIO-PROTOCOL, 6(21).

Lindemann, L., Jaeschke, G., Michalon, A., Vieira, E., Honer, M., Spooren, W., Porter, R., Hartung, T., Kolczewski, S., Büttelmann, B., Flament, C., Diener, C., Fischer, C., Gatti, S., Prinssen, E., Parrott, N., Hoffmann, G. and Wettstein, J., 2011. CTEP: A Novel, Potent, Long-Acting, and Orally Bioavailable Metabotropic Glutamate Receptor 5 Inhibitor. Journal of Pharmacology and Experimental Therapeutics, 339(2), pp.474-486.

Loane, D., Stoica, B., Pajoohesh-Ganji, A., Byrnes, K. and Faden, A., 2009. Activation of Metabotropic Glutamate Receptor 5 Modulates Microglial Reactivity and Neurotoxicity by Inhibiting NADPH Oxidase. Journal of Biological Chemistry, 284(23), pp.15629-15639.

Loane, D., Stoica, B., Tchantchou, F., Kumar, A., Barrett, J., Akintola, T., Xue, F., Conn, P. and Faden, A., 2014. Novel mGluR5 Positive Allosteric Modulator Improves Functional Recovery, Attenuates Neurodegeneration, and Alters Microglial Polarization after Experimental Traumatic Brain Injury. Neurotherapeutics, 11(4), pp.857-869.

Lull, M. and Block, M., 2010. Microglial activation and chronic neurodegeneration. Neurotherapeutics, 7(4), pp.354-365. 
Maiese, K., 2015. Targeting molecules to medicine with mTOR, autophagy and neurodegenerative disorders. British Journal of Clinical Pharmacology, 82(5), pp.1245-1266.

Mason, B. and Heyser, C., 2010. Acamprosate: A Prototypic Neuromodulator in the Treatment of Alcohol Dependence. CNS \& Neurological Disorders - Drug Targets, 9(1), pp.23-32.

Mass, E., Jacome-Galarza, C., Blank, T., Lazarov, T., Durham, B., Ozkaya, N., Pastore, A., Schwabenland, M., Chung, Y., Rosenblum, M., Prinz, M., Abdel-Wahab, O. and Geissmann, F., 2017. A somatic mutation in erythro-myeloid progenitors causes neurodegenerative disease. Nature, 549(7672), pp.389-393.

Matosin, N., Newell, K., Quidé, Y., Andrews, J., Teroganova, N., Green, M. and Fernandez, F., 2017. Effects of common GRM5 genetic variants on cognition, hippocampal volume and mGluR5 protein levels in schizophrenia. Brain Imaging and Behavior, 12(2), pp.509-517.

Mecha, M., Feliú, A., Carrillo-Salinas, F., Rueda-Zubiaurre, A., Ortega-Gutiérrez, S., de Sola, R. and Guaza, C., 2015. Endocannabinoids drive the acquisition of an alternative phenotype in microglia. Brain, Behavior, and Immunity, 49, pp.233-245.

Michelucci, A., Heurtaux, T., Grandbarbe, L., Morga, E. and Heuschling, P., 2009. Characterization of the microglial phenotype under specific pro-inflammatory and anti-inflammatory conditions: Effects of oligomeric and fibrillar amyloid- $\beta$. Journal of Neuroimmunology, 210(1-2), pp.3-12.

Mittelbronn, M., Dietz, K., Schluesener, H. and Meyermann, R., 2001. Local distribution of microglia in the normal adult human central nervous system differs by up to one order of magnitude. Acta Neuropathologica, 101(3), pp.249-255.

Nayak, D., Roth, T. and McGavern, D., 2014. Microglia Development and Function. Annual Review of Immunology, 32(1), pp.367-402.

Niswender, C. and Conn, P., 2010. Metabotropic Glutamate Receptors: Physiology, Pharmacology, and Disease. Annual Review of Pharmacology and Toxicology, 50(1), pp.295-322.

Norden, D., Trojanowski, P., Villanueva, E., Navarro, E. and Godbout, J. (2016). Sequential activation of microglia and astrocyte cytokine expression precedes increased iba-1 or GFAP immunoreactivity following systemic immune challenge. Glia, 64(2), pp.300-316.

Orihuela, R., McPherson, C. and Harry, G. (2015). glial M1/M2 polarization and metabolic states. British Journal of Pharmacology, 173, pp.649-665. 
Paolicelli, R., Bolasco, G., Pagani, F., Maggi, L., Scianni, M., Panzanelli, P., Giustetto, M., Ferreira, T., Guiducci, E., Dumas, L., Ragozzino, D. and Gross, C., 2011. Synaptic Pruning by Microglia Is Necessary for Normal Brain Development. Science, 333(6048), pp.1456-1458.

Perluigi, M., Di Domenico, F. and Butterfield, D., 2015. mTOR signaling in aging and neurodegeneration: At the crossroad between metabolism dysfunction and impairment of autophagy. Neurobiology of Disease, 84, pp.39-49.

Politis, M., 2012. Imaging of microglia in patients with neurodegenerative disorders. Frontiers in Pharmacology, 3.

Qin, K., Dong, C., Wu, G. and Lambert, N., 2011. Inactive-state preassembly of Gq-coupled receptors and $\mathrm{Gq}$ heterotrimers. Nature Chemical Biology, 7(10), pp.740-747.

Renner, M., Lacor, P., Velasco, P., Xu, J., Contractor, A., Klein, W. and Triller, A., 2010. Deleterious Effects of Amyloid $\beta$ Oligomers Acting as an Extracellular Scaffold for mGluR5. Neuron, 66(5), pp.739-754.

Revett,, T., Baker, G., Jhamandas, J. and Kar, S., 2013. Glutamate system, amyloid $\beta$ peptides and tau protein: functional interrelationships and relevance to Alzheimer disease pathology. Journal of Psychiatry \& Neuroscience, 38(1), pp.6-23.

Rondard, P., Goudet, C., Kniazeff, J., Pin, J. and Prézeau, L., 2011. The complexity of their activation mechanism opens new possibilities for the modulation of mGlu and GABAB class C G protein-coupled receptors. Neuropharmacology, 60(1), pp.82-92.

Sackmann, V., Ansell, A., Sackmann, C., Lund, H., Harris, R., Hallbeck, M. and Nilsberth, C., 2017. Anti-inflammatory (M2) macrophage media reduce transmission of oligomeric amyloid beta in differentiated SH-SY5Y cells. Neurobiology of Aging, 60, pp.173-182.

Sassone-Corsi, P., 2012. The Cyclic AMP Pathway. Cold Spring Harbor Perspectives in Biology, 4(12), pp.a011148-a011148.

Saxton, R. and Sabatini, D., 2017. mTOR Signaling in Growth, Metabolism, and Disease. Cell, 169(2), pp.361-371.

Schildge, S., Bohrer, C., Beck, K. and Schachtrup, C., 2013. Isolation and Culture of Mouse Cortical Astrocytes. Journal of Visualized Experiments, (71).

Schulte, G. and Kozielewicz, P., 2020. Structural insight into Class F receptors - What have we learnt regarding agonist-induced activation?. Basic \& Clinical Pharmacology \& Toxicology, 126(S6), pp.17-24. 
Showkat, M., Beigh, M. and Andrabi, K., 2014. mTOR Signaling in Protein Translation Regulation: Implications in Cancer Genesis and Therapeutic Interventions. Molecular Biology International, 2014, pp.1-14.

Sekar, R., Singh, K., Arokiaraj, A. and Chow, B., 2016. Pharmacological Actions of Glucagon-Like Peptide-1, Gastric Inhibitory Polypeptide, and Glucagon. International Review of Cell and Molecular Biology, pp.279-341.

Sonenberg, N. and Hinnebusch, A., 2009. Regulation of Translation Initiation in Eukaryotes: Mechanisms and Biological Targets. Cell, 136(4), pp.731-745.

Streit, W., Mrak, R. and Griffin, W., 2004. Microglia and neuroinflammation: a pathological perspective. Journal of Neuroinflammation, 1(1), p.14.

Tang, Y. and Le, W. (2015). Differential Roles of M1 and M2 Microglia in Neurodegenerative Diseases. Molecular Neurobiology, 53(2), pp.1181-1194.

Tilleux, S., Berger, J. and Hermans, E., 2007. Induction of astrogliosis by activated microglia is associated with a down-regulation of metabotropic glutamate receptor 5. Journal of Neuroimmunology, 189(1-2), pp.23-30.

Ulrich, J., Finn, M., Wang, Y., Shen, A., Mahan, T., Jiang, H., Stewart, F., Piccio, L., Colonna, M. and Holtzman, D., 2014. Altered microglial response to $A \beta$ plaques in APPPS1-21 mice heterozygous for TREM2. Molecular Neurodegeneration, 9(1), p.20.

Wu, S., Pan, B., Tsai, S., Chiang, Y., Huang, B., Mo, F. and Kuo, Y., 2020. BDNF reverses aging-related microglial activation. Journal of Neuroinflammation, 17(1).

Wu, H., Wang, C., Gregory, K., Han, G., Cho, H., Xia, Y., Niswender, C., Katritch, V., Meiler, J., Cherezov, V., Conn, P. and Stevens, R., 2014. Structure of a Class C GPCR Metabotropic Glutamate Receptor 1 Bound to an Allosteric Modulator. Science, 344(6179), pp.58-64.

Xu, Q., Bernardo, A., Walker, D., Kanegawa, T., Mahley, R. and Huang, Y., 2006. Profile and Regulation of Apolipoprotein E (ApoE) Expression in the CNS in Mice with Targeting of Green Fluorescent Protein Gene to the ApoE Locus. Journal of Neuroscience, 26(19), pp.4985-4994.

Yamazaki, Y., Zhao, N., Caulfield, T., Liu, C. and Bu, G., 2019. Apolipoprotein E and Alzheimer disease: pathobiology and targeting strategies. Nature Reviews Neurology, 15(9), pp.501-518. 
Yang, T., Liu, Y., Zhao, L., Wang, H., Yang, N., Dai, S. and He, F., 2017. Metabotropic glutamate receptor 5 deficiency inhibits neutrophil infiltration after traumatic brain injury in mice. Scientific Reports, 7(1).

Yang, D., Zhou, Q., Labroska, V., Qin, S., Darbalaei, S., Wu, Y., Yuliantie, E., Xie, L., Tao, H., Cheng, J., Liu, Q., Zhao, S., Shui, W., Jiang, Y. and Wang, M., 2021. G protein-coupled receptors: structure- and function-based drug discovery. Signal Transduction and Targeted Therapy, 6(1).

Ye, X., Zhu, M., Che, X., Wang, H., Liang, X., Wu, C., Xue, X. and Yang, J., 2020. Lipopolysaccharide induces neuroinflammation in microglia by activating the MTOR pathway and downregulating Vps34 to inhibit autophagosome formation. Journal of Neuroinflammation, 17(1).

Yu, J. and Rasenick, M. (2012). Receptor signaling and the cell biology of synaptic transmission. Neurobiology of Psychiatric Disorders, pp.9-35.

Yu, Y. and Ye, R., 2014. Microglial $A \beta$ Receptors in Alzheimer's Disease. Cellular and Molecular Neurobiology, 35(1), pp.71-83.

Zhang, Y., Fan, J., Gu, L., Yang, H., Zhan, S. and Zhang, H., 2021. Metabotropic glutamate receptor 5 inhibits $\alpha$-synuclein-induced microglia inflammation to protect from neurotoxicity in Parkinson's disease. Journal of Neuroinflammation, 18(1).

Zhang, L., Zhang, J. and You, Z. (2018). Switching of the Microglial Activation Phenotype Is a Possible Treatment for Depression Disorder. Frontiers in Cellular Neuroscience, 12.

Zheng Zhang, Scott Schwartz, Lukas Wagner, and Webb Miller (2000), "A greedy algorithm for aligning DNA sequences", J Comput Biol 2000; 7(1-2) pp.203-14.

Zheng, Z. and Wong, K., 2019. Microglial activation and polarization after subarachnoid hemorrhage. Neuroimmunology and Neuroinflammation, 2019.

Zhou, H., Liao, J., Aloor, J., Nie, H., Wilson, B., Fessler, M., Gao, H. and Hong, J. (2012). CD11b/CD18 (Mac-1) is a Novel Surface Receptor for Extracellular Double-Stranded RNA To Mediate Cellular Inflammatory Responses. The Journal of Immunology, 190(1), pp.115-125.

Zotova, E., Bharambe, V., Cheaveau, M., Morgan, W., Holmes, C., Harris, S., Neal, J., Love, S., Nicoll, J. and Boche, D., 2013. Inflammatory components in human Alzheimer's disease and after active amyloid- $\beta 42$ immunization. Brain, 136(9), pp.2677-2696. 


\section{APPENDICES}

\section{Appendix A}

Table 1. All abbreviations used throughout paper, listed alphabetically.

\begin{tabular}{|l|l|}
\hline 4E-BP1 & $\begin{array}{l}\text { Eukaryotic translation initiation factor } \\
\text { 4E-binding protein 1 }\end{array}$ \\
\hline AD & Alzheimer's Disease \\
\hline ATP & Adenosine Triphosphate \\
\hline BSC & Biological Safety Cabinet \\
\hline CNS & Central Nervous System \\
\hline CM & Complete Media \\
\hline DMEM & Dulbecco's Modified Eagle Medium \\
\hline GPCRs & G-coupled Protein Receptors \\
\hline IL-6 & Interleukin 6 \\
\hline IL-15 & Interleukin 15 \\
\hline mGluR & Metabotropic Glutamate Receptor \\
\hline mGluR5 & Metabotropic Glutamate Receptor 5 \\
\hline mTOR & Mechanistic target of rapamycin \\
\hline P70S6K & Ribosomal protein S6 kinase beta-1 \\
\hline PBS & Phosphate Buffered Saline \\
\hline PD & Tris-buffered saline \\
\hline TBS & Tris-buffered saline with 0.1\% tween \\
\hline TBS-T & \\
\hline
\end{tabular}




\section{Appendix B}

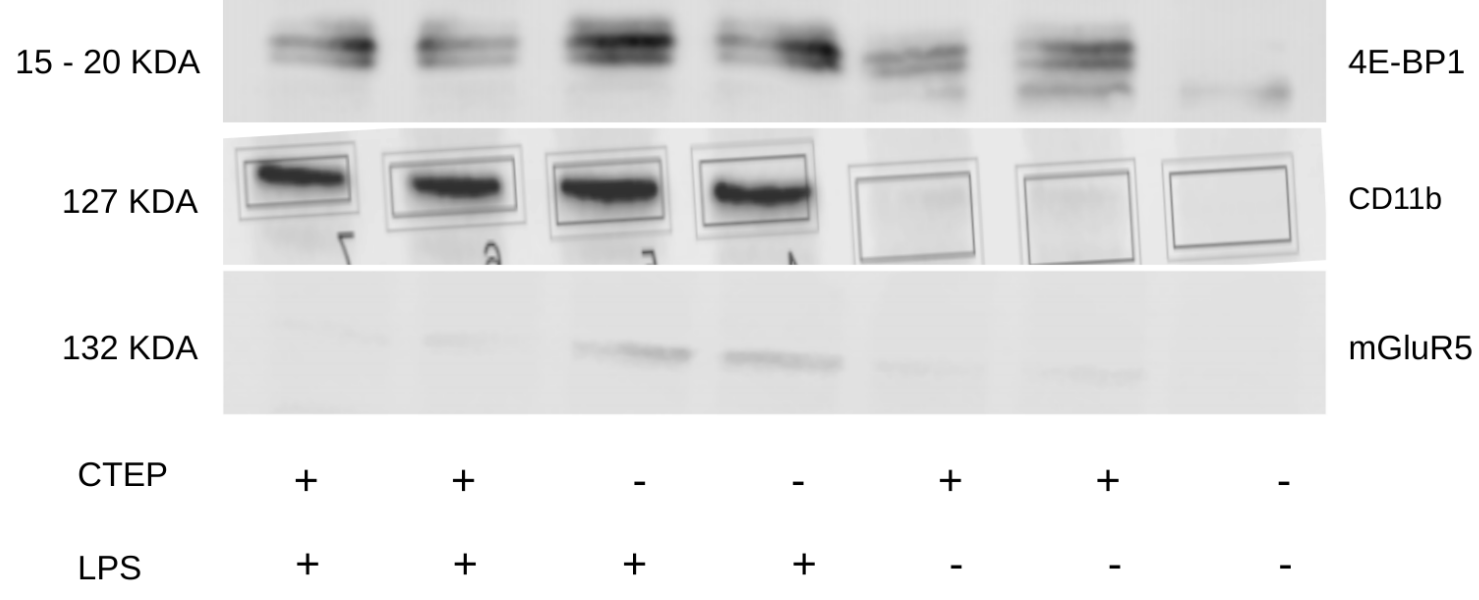

Figure 5. Western blot 4E-BP1, CD11b and mGluR5 with CTEP + LPS in BV2 cells after 24 hours for each treatment. Biological sample 2. 


\section{Appendix C}

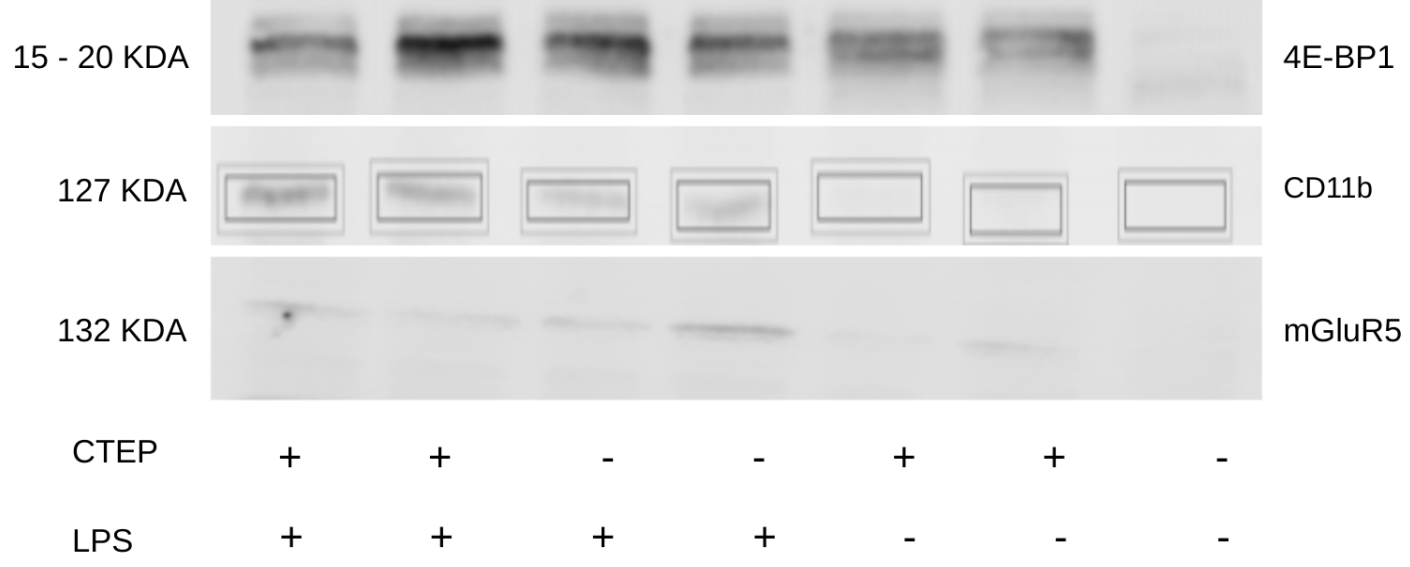

Figure 6. Western blot 4E-BP1, CD11b and mGluR5 with CTEP + LPS in BV2 cells after 24 hours for each treatment. Biological sample 3. 


\section{Appendix D}

$15-20$ KDA

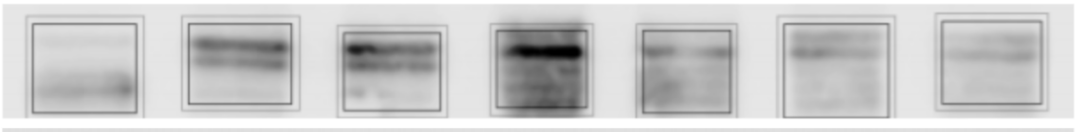

127 KDA

132 KDA

(1)
4E-BP1

CD11B

mGluR5

$\begin{array}{llllllll}\text { CTEP } & + & + & - & - & + & + & - \\ \text { LPS } & + & + & + & + & - & - & -\end{array}$

Figure 7. Western blot 4E-BP1, CD11b and mGluR5 with CTEP + LPS in BV2 cells after 2 hours for each treatment. Biological sample 2. 


\section{Appendix E}

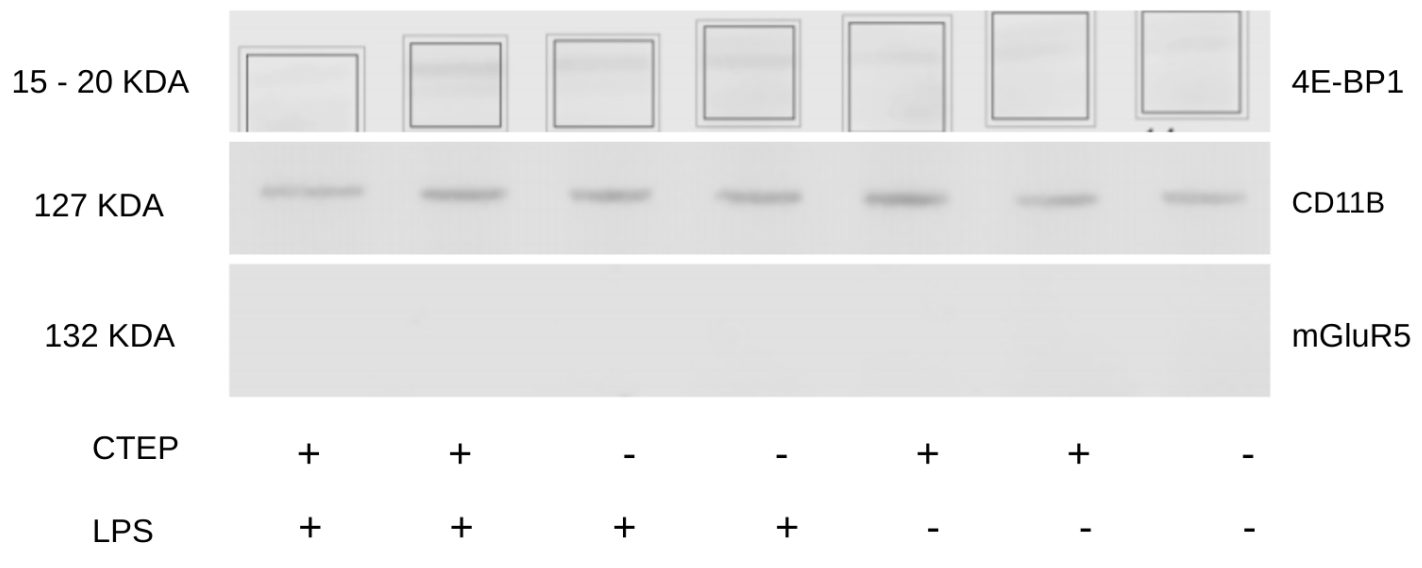

Figure 8. Western blot 4E-BP1, CD11b and mGluR5 with CTEP + LPS in BV2 cells after 2 hours for each treatment. Biological sample 3. 